\title{
'By Merit Raised to That Bad Eminence': Christopher Merrett, Artisanal Knowledge, and Professional Reform in Restoration London
}

\author{
AARON MAUCK*
}

\begin{abstract}
This article examines the career and reform agenda of Christopher Merrett as a means of evaluating the changing conditions of medical knowledge production in late seventeenth-century London. This period was characterised by increasing competition between medical practitioners, resulting from the growing consumer demand for medical commodities and services, the reduced ability of elite physicians to control medical practice, and the appearance of alternative methods of producing medical knowledge - particularly experimental methods. This competition resulted in heated exchanges between physicians, apothecaries, and virtuosi, in which Merrett played an active part. As a prominent member of both the Royal Society and the Royal College of Physicians, Merrett sought to mediate between the two institutions by introducing professional reforms designed to alleviate competition and improve medical knowledge. These reforms entailed sweeping changes to medical regulation and education that integrated the traditional reliance on Galenic principles with knowledge derived from experiment and artisanal practices. The emphasis Merrett placed on the trades suggests the important role artisanal knowledge played in his efforts to reorganise medicine and improve knowledge of bodily processes.
\end{abstract}

Keywords: Christopher Merrett; Artisanal Knowledge; Natural History; Natural Philosophy; Galenism; Royal Society; Royal College of Physicians; Physicians; Virtuosi; Apothecaries; Chemical Physicians; Professional Reform; Medical Marketplace; Competition; Pamphlet War

\section{Introduction}

The founding of the Royal Society in 1660 proved a watershed moment for the seventeenth-century's nascent natural history movement, providing its advocates with

(C) Aaron Mauck, 2012.

*Aaron Mauck, Robert Wood Johnson

Health \& Society Scholar, University of Michigan
School of Public Health, SPH Tower,

Room 3632, 1415 Washington Heights, Ann Arbor, MI 48109, USA. Email: amauck@umich.edu 
public recognition of their approach to knowledge-making and a focal point around which to organise their activities. Although the early Royal Society is often perceived as principally concerned with problems of nature far grander than physical health, many physicians interested in reforming clinical practices were also founding members, having embraced the new philosophy as a tonic to the related problems of excessive market competition and limited medical efficacy then confronting the profession. ${ }^{1}$ While the Royal Society furnished these physicians with a new source of institutional authority for their proposed reforms, it also exposed certain competitive tensions between the approaches to knowledge privileged by physicians and virtuosi. These tensions ultimately undermined efforts to change the way in which medicine was practised.

The career and reform agenda of Christopher Merrett offers a particularly illuminating window into the challenges would-be reformers confronted during the second half of the seventeenth century. As a well-connected member of London's medical elite, Merrett appeared ideally situated to bring about reform. He had taken his medical degree in 1643 at Gloucester Hall, Oxford, after which he moved to the city and set up a highly successful private practice. By 1651, he had been elected a Fellow of the Royal College of Physicians, and could count both Baldwin Hamey Jr and William Harvey as personal friends. ${ }^{2}$ In 1653, Harvey even handpicked Merrett to serve as first Harveian Librarian to his collection that had recently been installed at the College House at Amen Corner, ${ }^{3}$ for which Merrett was rewarded with a remittance on taxes and a $£ 20$ annual stipend. ${ }^{4}$ Merrett eventually went on to serve several times as Censor for the College, charged with hearing professional grievances and regulating practice. ${ }^{5}$

Merrett may have reached the pinnacle of his profession, but he was no apologist for elite practice. As was true of many younger physicians trained at Oxford and Cambridge, ${ }^{6}$ he had cultivated a strong interest in the methods and conclusions of natural history, seeing these as a valuable complement to the natural philosophical approach that dominated traditional medical education. Shortly after arriving in London, he became involved with the influential '1645 Group', a heterodox mixture of natural historians,

\footnotetext{
${ }^{1}$ On the role of physicians in the early Royal Society, see Michael Hunter, The Royal Society and its Fellows 1660-1700: The Morphology of an Early Scientific Institution (Chalfont St Giles: British Society for the History of Science, 1994); idem, Establishing the New Science: The Experience of the Early Royal Society (Woodbridge: Boydell Press, 1989); Roy Porter, 'The Early Royal Society and the Spread of Medical Knowledge', in Roger French and Andrew Wear (eds), The Medical Revolution of the Seventeenth Century (Cambridge: Cambridge University Press, 1989), 272-93.

${ }^{2}$ Although a relatively traditional and scholarly physician with little interest in the new philosophy, Hamey nonetheless cultivated friendships with several experimentally-minded younger physicians, including Merrett, George Ent and Christopher Wharton. See Ralph Palmer, 'The Life of the Most Eminent Dr Baldwin Hamey' (unpublished MS: Royal College of Physicians, 1733). The National
}

Archives (hereafter TNA) Royal College of Physicians (hereafter RCP): GB 0113 MS-PALMR.

${ }^{3}$ The collection at this time primarily consisted of books, although it also contained anatomical specimens and exotica similar to the standard stock of items in contemporary scientific cabinets. See Michael Hunter, Science and the Shape of Orthodoxy (Woodbridge: Boydell Press, 1995), 136.

${ }^{4}$ According to the terms of a 1653 lease on the property, Merrett was given a twenty-one-year lease with an annual rent of $£ 20$ : TNA RCP: LEGAC/SR/ $10 \mathrm{~A} / 4$.

${ }^{5}$ Charles Dodds, 'Christopher Merrett, FRCP (1614-1695), First Harveian Librarian', Proceedings of the Royal Society of Medicine, 47 (1954), 1053-6.

${ }^{6}$ In addition to Merrett, those who eventually became part of the Royal College included George Ent, Robert Goddard, and Francis Glisson. All eventually became founding members of the Royal Society. 


\section{Aaron Mauck}

physicians, and mathematicians who had gathered together at the behest of Theodore Haak with the hope of eventually actualising Francis Bacon's vision of a state-sponsored learned society. ${ }^{7}$ Merrett had further opportunities to explore natural history as Librarian of the Royal College, as the College House often served as a site for lectures and casual meetings on a wide range of experimental and natural historical subjects prior to the establishment of the Royal Society. ${ }^{8}$

When this event occurred, it therefore made sense that Merrett would be among the Royal Society's founders, and would become one of its most active members. ${ }^{9}$ As was the case at the Royal College, Merrett took on several administrative duties for the Royal Society, heading the committee on the history of trades, ${ }^{10}$ and contributing several papers to the Philosophical Transactions on artisanal production practices. ${ }^{11}$ Merrett also became a prolific author in the 1660s, writing books on subjects ranging from a translation of Antonio Neri's The Art of Glass ${ }^{12}$ to the Pinax Rerum Naturalium Britannicarum (a catalogue of British Flora considered one of the 'exceptional books by English authors,' according to the Italian visitor Lorenzo Magalotti), ${ }^{13}$ to a treatise on the diseases of wine. ${ }^{14}$ Although not all of these were well received - John Ray in

\footnotetext{
${ }^{7}$ For further discussion of the 1645 group, see R.G. Frank, 'The Physician as Virtuosi in Seventeenth Century England', in Barbara Shapiro and R.G. Frank (eds), English Scientific Virtuosi in the Sixteenth and Seventeenth Centuries (Los Angeles, CA: William Andrews Clark Memorial Library, 1979), 57-114; R.G. Frank, Harvey and the Oxford Physiologists: Scientific Ideas and Social Interaction (Berkeley, CA: University of California Press, 1980). The 1645 group was one of several Bacon-inspired societies that arose in this period, including the Invisible College, centred on Robert Boyle, and the Comenians, centred on Samuel Hartlib. There remains some debate as to which group constitutes the key predecessor to the Royal Society.

${ }^{8}$ As Charles Webster and others have noted, prior to the creation of the Royal Society the Royal College of Physicians encouraged a wide range of research interests, many of which were non-medical in nature. The institution only became more exclusively orientated towards medicine after 1660. See Charles Webster, 'The College of Physicians: "Solomon's House" in Commonwealth England', Bulletin of the History of Medicine, 41 (1967), 393-412.

${ }^{9}$ For a list of early personnel elections and discussion of the circumstances surrounding the founding of the Royal Society, see E.S. deBeer, 'The Earliest Fellows of the Royal Society', Notes and Records of the Royal Society 7, 2 (1950), 172-92; Hunter, The Royal Society, op. cit. (note 1).

${ }^{10}$ For further discussion of this project, see Walter Houghton, 'The History of Trades: Its Relation to Seventeenth-Century Thought', Journal of the History of Ideas, 2 (1941), 33-60; Kathleen Ochs, 'The Royal Society of London's History of Trades Programme', Notes and Records of the Royal Society, 39 (1985), 125-58.
}

\section{${ }^{11}$ Christopher Merrett, 'An Experiment of} Making Cherry-Trees, That Have Withered Fruit, to Bear Full and Good Fruit; and Recovering the Almost Withered Fruit', Philosophical Transactions of the Royal Society of London, 2 (1666), 455; idem, 'Observations Concerning the Uniting of Barks of Trees cut, to the Tree It Self', Philosophical Transactions of the Royal Society of London, 2 (1666), 453-4; idem, 'An Experiment on Aloe Americana Serrati-Folia Weighed; Seeming to Import a Circulation of the Sappe in Plants', Philosophical Transactions of the Royal Society of London, 2 (1666), 455-7; idem, 'A Description of Several Kinds of Granaries, as Those of London, of Dantzick, and in Muscovy', Philosophical Transactions of the Royal Society of London, 2 (1666), 464-7; 'The Art of Refining Lead', Philosophical Transactions of the Royal Society of London, 12 (1677), 1046-52; 'A Relation of the TinnMines, and Working of Tinn in the County of Cornwal', Philosophical Transactions of the Royal Society of London,12. (1677), 949-52.

${ }^{12}$ Antonio Neri, The Art of Glass, Wherein are Shown the Wayes to Make and Colour Glass, Pastes, Enamels, Lakes, and Other Curiosities (London: Printed by A.W. for Octavian Pulleyn, 1662).

${ }^{13}$ Christopher Merrett, Pinax rerum naturalium Britannicarum continensve getab lilia, animaliaet fossilia, in hacinsulâreppertain choatus (London: Printed by F. \& T. Warren for Cave Pulleyn, 1666).

${ }^{14}$ Walter Charleton and Christopher Merrett, Of the Mysterie of the Vintners (London, 1669). Merrett's address to the Royal Society on this subject, Some Observations Concerning the Ordering of Wine, was appended to Charleton's text. 
fact described his Pinax as a 'bungling' work in a letter to Martin Lister - his sheer breadth of interests solidified his reputation as an authority on applied natural history. ${ }^{15}$

Given these intellectual contributions, not to mention the prominent part he played in the affairs of the Royal College and Royal Society throughout the middle of the seventeenth century, Christopher Merrett has been remarkably overlooked in accounts of medicine during the Restoration. The little work that has been published directly on him has remained almost exclusively restricted to his activities as a naturalist or to his role in early English wine production. ${ }^{16}$ While it is thus possible that Merrett is better known among viniculturalists than historians of science, he in fact played a prominent part in the internecine professional and intellectual troubles that characterised this period.

As Harold J. Cook has shown, the establishment of the Royal Society exacerbated epistemological tensions between the system of natural philosophy favoured by traditional medicine and the system of natural history then in vogue among chemical physicians and virtuosi. As a rule, advocates of natural philosophy continued to promote an overarching $\log o s$, arrived at primarily through the methods of disputation and reason, while natural history promoted the production of general knowledge claims through the accumulation of singular instances of natural phenomena using observation and experimentation. ${ }^{17}$ In the context of medical practice, this difference manifested itself in a tension between a passive and preventative approach to care rooted in Galenic first principles and privileged by elite physicians, and an active interventionalist pursuit of cures that was rooted in empiricism and privileged by chemical physicians and professional apostates. To many, these two approaches seemed fundamentally and resolutely opposed.

As a member of both the Royal College and the Royal Society, these tensions inevitably shaped Merrett's strategy of reform. Rather than choosing a single side, he instead sought to integrate elements of both into a new medical approach. In the two decades following the establishment of the Royal Society, he thus took part in a campaign to bring more experimentation into medicine, and thereby bring more physicians into the Royal Society's fold. ${ }^{18}$ By embracing knowledge derived from artisanal work and proposing an expansion of physicians' activities to include drug production, ${ }^{19}$ he hoped to enlarge the limits of

\footnotetext{
${ }^{15}$ Charles Raven, John Ray, Naturalist: His Life and Works, 2nd edn (Cambridge: Cambridge University Press, 1950), 143.

${ }^{16}$ See for instance Albert Koinm, 'Christopher Merrett's Use of Experiment', Notes and Records of the Royal Society of London, 54, 1 (2000): 23-32; M.J. Foley, 'Christopher Merrett's Pinax rerum naturalium britannicarum (1666): Annotations to What is Believed to be the Author's Personal Copy', Archives of Natural History, 32, 2 (2006), 191-201; Michael Best, 'The Mystery of the Vintners', Agricultural History, 50, 2 (1976), 362-76.

${ }^{17}$ Harold J. Cook, 'The New Philosophy and Medicine', in David C. Lindberg and Robert S.Westman (eds), Reappraisals of the Scientific Revolution (Cambridge: Cambridge University Press, 1990): 397-436.

${ }^{18}$ Reforming traditional medicine through greater reliance on experiment and drug production had long
}

been an interest of medical practitioners, especially those trained in the Paracelsian or Helmontian traditions. See Charles Webster, The Great Instauration: Science, Medicine, and Reform 1626-1660 (New York: Holmes and Meier, 1976); A.G. Debus, 'Chemists, Physicians, and Changing Perspectives on the Scientific Revolution', Isis, 89, 1 (1998), 66-81.

${ }^{19}$ Recent historical work on artisanal epistemologies has focused extensively on the relationship between trade knowledge and natural philosophical knowledge. See for instance Alan Gabbey, 'Between Ars and Philosophia Naturalis: Reflections on the Historiography of Early Modern Mechanics', in J.V. Field and Frank James (eds), Renaissance and Revolution: Humanists, Scholars, Craftsman, and Natural Philosophers in Early Modern Europe (Cambridge: Cambridge University Press, 1992), 133-45; Pamela Smith, The Body of the 


\section{Aaron Mauck}

established elite practice. ${ }^{20}$ Importantly, however, experimentation and intervention were not to replace observation and prevention as the foundation of treatment. The logos Galen had provided would continue to dominate medical practice, even if it was to be increasingly supplemented by the fruits of experiment. ${ }^{21}$

Disagreements over the wisdom of this approach eventually resulted in a schism within the Royal College between enthusiasts of the new philosophy, and more circumspect members. This soon turned into a pamphlet war, which raged between physicians, virtuosi, and apothecaries from 1668 to $1671 .^{22}$ Although Merrett was hardly alone in promoting closer relations between the two professional bodies, these events like as not contributed to his fall from professional grace at this time, which ultimately resulted in his alienation and eventual expulsion from the Royal College in 1681.

These disagreements hinged on suspicions many held about the true intentions of the Royal Society - and Merrett himself - towards elite practice. What was the status of the physician to be in the new philosophy? How would the apparent democracy of knowledge inherent in it translate into changes in the organisation of medicine? Would its ascendancy mean that those with chemical or empirical leanings (or even tradesmen) would, in the future, be legitimately allowed to practise medicine alongside universitytrained physicians? By promoting the search for cures and proposing to link medicine to new experimental practices, Merrett appeared to some to be suggesting as much. ${ }^{23}$

Artisan: Art and Experience in the Scientific Revolution (Chicago, IL: University of Chicago Press, 2004).

${ }^{20}$ The problem of maintaining professional standards of practice in the face of this competition has received extensive historical consideration. See Charles F. Mullett, 'Physician Versus Apothecary, 1669-1671: An Episode in an Age-Long Controversy', Scientific Monthly, 49 (1939), 558-65; Harold J. Cook, The Decline of the Old Medical Regime in Stuart London (Ithaca, NY: Cornell University Press, 1986); Harold J. Cook, 'Good Advice and Little Medicine: The Professional Authority of Early Modern English Physicians', The Journal of British Studies 33, 1 (1994), 1-33. The relationship between physicians and apothecaries remained tense throughout the second half of the seventeenth century, and was particularly acrimonious during the 1668-73 pamphlet war discussed here. On the complex relationship between the Royal Society and the Society of Apothecaries at this time, see W.H.G Armytage, 'The Royal Society and the Apothecaries, 1660-1722', Notes and Transactions of the Royal Society of London 11, 1 (1954), 22-37.

${ }^{21}$ This approach to reform was consistent with Bacon's tripartite of medicine, which acknowledged the importance of both prevention and treatment, as well as the prolongation of life.While Bacon influenced most views of medical reform, most actual reformers focused primarily on treatment and ignored prevention. On Bacon's model, see Francis Bacon, De Dignitate Et Augmentis Scientiarum [1624] (repr.

New York: Nabu Press, 2010).

${ }^{22}$ Such exchanges of pamphlets became increasingly common in the late seventeenth century, as increasing consumer pressures on the medical marketplace led to an increase in the volume of medical publishing and the development of new publication formats.See Elizabeth Lane Furdell, Publishing and Medicine in Early Modern England (Rochester, NY: University of Rochester Press, 2002).

${ }^{23}$ The pursuit of such cures had largely inspired the activities of the proposed Society of Chemical Physicians that had previously troubled the Royal College of Physicians. See Henry Thomas, 'The Society of Chymical Physicians: An Echo of the Great Plague of London, 1665', in E. Ashworth Underwood (ed.), Science, Medicine, and History: Essays on the Evolution of Scientific Thought and Medical Practice Written in Honour of Charles Singer (Oxford: Oxford University Press, 1953), 55-71; P.M. Rattansi, 'The Helmontian-Galenist Controversy in Restoration England', Ambix 12 (1964), 1-23; Charles Webster, 'English Medical Reformers of the Puritan Revolution: A Background to the "Society of Chymical Physicians", Ambix, 14 (1967), 16-41; Harold J. Cook, 'The Society of Chemical Physicians, the New Philosophy, and the Restoration Court', Bulletin of the History of Medicine, 61 (1987), 61-77. 


\section{'By Merit Raised to That Bad Eminence'}

While it is unlikely that this was Merrett's intention, the reforms that he had hoped would appeal to both sides ultimately proved appealing to neither. For all their possible merits, they reflected the aspirations that younger physicians like himself had held for their profession prior to the creation of the Royal Society, when co-operation between physicians and virtuosi still seemed possible. In the altered political and institutional climate of the 1660s and 1670s this aspiration seemed less idealistic than downright suspect.

In the sections that follow, I explore the relationship between Merrett's own career path and the programme of reform he pursued, focusing primarily on his proposals for alleviating competition from apothecaries and reforming medical education. Both reforms are discussed in the context of the rapidly changing professional conditions he encountered after 1660. Ultimately, his failure to bring about a reconciliation between physicians and virtuosi through these measures did not prove that their two approaches to knowledge production were antithetical, but rather that the opportunities to develop such a shared approach were limited in the climate of mutual mistrust that prevailed.

\section{Confronting Challenges to the Professional Order}

Although the birth of the Royal Society was greeted as a happy event by younger Fellows of the Royal College such as Merrett, many older Fellows saw in its methods an existential threat to their way of practising. English physicians had battled sustained anti-authoritarian challenges to Galenism throughout the first half of the seventeenth century, as practitioners steeped in Paracelsian and Helmontian principles sought to overturn the Galenic reliance on diagnosis and prognosis in favour of botanical or chemical remedies. To such practitioners, the Royal College often seemed little more than a backward group of monopolists, out of touch with the intellectual revolution then shaking the foundations of the profession on the Continent.

In the charged and unpredictable political climate of the Interregnum, many advocates of chemical remedies had been given free rein to criticise physicians, and to peddle their treatment methods with little threat of prosecution. While the Royal College still possessed the legal authority to regulate practice, and in fact desperately needed to exercise this authority in order to alleviate growing commercial threats from apothecaries and irregular practitioners operating in the city, it lacked the governmental backing to enforce its legal claims. ${ }^{24}$

The establishment of the Royal Society compounded this impotence by encouraging the self-proclaimed 'chemical physicians' to obtain legal justification for their own approach to medicine. Although the careful observer could note significant differences between virtuosi and chemical physicians, especially concerning their methods for producing truth claims, ${ }^{25}$ the Royal Society certainly seemed to espouse democratic and empirical principles similar to those expressed by vocal critics of elite medicine such as Noah Biggs, Nicholas Culpeper, and George Thomson. Given the strength of political support behind the Royal Society, a similar society rooted in chemistry and

\footnotetext{
${ }^{24}$ Cook, Decline, op. cit. (note 20), Chs 3 and 4.

${ }^{25}$ Steven Shapin, A Social History of Truth (Chicago: University of Chicago Press, 1994); Steven
}

Shapin, 'The House of Experiment in Seventeenth Century England', in idem, Never Pure (Baltimore, MD: Johns Hopkins University Press, 2010), 59-88. 


\section{Aaron Mauck}

aimed at the production of new medical cures seemed an increasing possibility. The result was a 1664-5 campaign to establish a royal charter for the Society of Chemical Physicians, justified in large part by the vogue for the new philosophy and its apparent similarities to chemical medicine. While this attempt ultimately failed (albeit barely), the rhetorical use the new philosophy was put to in promoting the chemical physicians' claims underscored fundamental similarities between the virtuosi and some of the staunchest enemies of the Royal College. $^{26}$

By the time plague returned to London in early 1665 , relations between physicians and the virtuosi had thus declined precipitously. Many older Fellows of the College had been intellectually wary of the new philosophy from the start, even if they accepted the interest that younger Fellows expressed in it. But the growing affinities between the chemical physicians and the virtuosi suggested that a more serious usurpation of their authority might be underway.

The Great Plague of 1665-6 eroded whatever goodwill remained by initiating a series of disasters for the Royal College and for Merrett personally. As the outbreak increased with the approach of summer, most licenced physicians chose to flee to the countryside in pursuit of their aristocratic clientele. The city was thus left virtually devoid of physicians, with the remaining Londoners relying on irregular practitioners and apothecaries to address their medical needs.

As Harveian Librarian and a resident of the College House, Merrett initially chose to stay behind to protect his own property and the collection of books and specimens that had been left in his charge. It is unclear whether he continued to practise during this time, or served among the few plague doctors then walking the streets, but this seems unlikely given that he also eventually fled out of fear for his family's safety. Before leaving, however, he took the precaution of securing one thousand pounds and the most valuable items from the collection in an iron chest. This measure proved ineffective, as during his absence thieves broke into the College House and absconded with the chest's contents.

Another outbreak of plague the following summer brought with it a second disaster. Choosing to return to London ahead of his colleagues, Merrett was essentially alone in the College House when fire broke out in the city on 2 September. When it reached Amen Corner on the evening of 4 September, it was apparent that the College House would soon be destroyed. Merrett and the College bedel therefore set about removing the most valuable items from the collection to bring a safe distance away from the blaze. ${ }^{27}$ Together, they were able to salvage 148 books (out of an estimated 1,300), the Annals of the Royal College, and portraits of Simeon Fox and William Harvey that Merrett had cut out of their frames. Otherwise, little of the collection or the remaining college records survived. ${ }^{28}$

Rather than being praised for rescuing the few items he was able to, Merrett was widely blamed for the damage done to the collection, and ultimately censured for failing to save

\footnotetext{
${ }^{26}$ Harold J. Cook, 'The Society of Chemical Physicians, the Royal Society, and the Restoration Court', Bulletin of the History of Medicine, 61, 1 (1987), 61-77.
}

\footnotetext{
${ }^{27}$ A vivid account of Merrett's response to the fire was provided by his son during a subsequent court proceeding between Merrett and the Royal College. See TNARCP-LEGAC/ENV 230.

${ }^{28}$ TNA RCP-LEGAC/ENV 90.
} 
more. Some of his colleagues were perhaps rankled by his earlier readiness to abandon the College House to thieves, although it has also been suggested that they may have wished to deflect their personal culpability in fleeing London in the first place. ${ }^{29}$

Whether or not Merrett was treated fairly in the aftermath of these events, the College leadership were justifiably concerned with the potential consequences of the destruction. Throughout the previous decade, the Royal College had tried in vain to reassert its control over practice in London, after a 1656 court decision had called into question the College's statutory authority on this matter. ${ }^{30}$ As librarian, Merrett had been expected to produce sufficient documentary evidence to support their original charter from Henry VIII, and had in fact published a book in 1660 outlining the legal powers of the Royal College. The Royal College nonetheless lost a subsequent 1665 appeal to Parliament to widen its regulatory power, and the destruction of the records promised to make future legal or political manoeuvres of this sort more difficult. ${ }^{31}$

Worse still, the disappearing act the professional elite had performed during the previous two summers further compromised their already shaky reputation with the public. Noting an exchange with Jonathan Goddard after the first outbreak of plague in 1665, Samuel Pepys (hardly an enemy of the profession) expressed scorn at the rationale commonly provided for their exodus: 'Dr Goddard did fill us with talke, in defence of his and his fellow physicians going out of towne in the plague-time; saying that their particular patients were most gone out of towne, and they left at liberty; and a great deal more, \&c. ${ }^{32}$ Provided they did not die, the apothecaries and chemical practitioners who remained in London during the plague could take advantage of this absence by expanding their own practices, thus increasing their commercial clout (and likely their popular esteem) at the expense of their rivals.

For Merrett, these setbacks to the profession were compounded by his personal destitution. Having lost all his property, including his considerable personal library, Merrett's only remaining possessions appear to have been those he had rescued from the collection. His choice to keep these perhaps reflected his hope of being reinstalled as Harveian Librarian once new accommodation for the Royal College was found. Instead, the College ultimately chose to abolish his post, and in 1669 paid him fifty pounds to surrender the lease he had held on the College House.

\section{The Pamphlet War and the Search for a Middle Ground}

The state of disarray in which the Royal College found itself following the destruction of the College House was reflected in a fractious change in its internal power structure. In 1667, the older conservative faction that had led the College since 1655 gave way to a

\footnotetext{
${ }^{29}$ Dodds, op. cit. (note 5).

${ }^{30}$ This case involved the prosecution of $\mathrm{Dr}$ Trigge, an irregular practitioner who had been fined and imprisoned in 1631 and 1637 on charges of malpractice. Trigge successfully painted the College as an unjust monopoly illegally prohibiting the activities of honest practitioners. For an account of the effects of this case, see Cook, Decline, op. cit. (note 20), Ch.3.
}

\footnotetext{
${ }^{31}$ Christopher Merrett, A Collection of Acts of Parliament, Charters, Trials at Law, and Judges Opinions concerning Those Grants of the Colledge of Physicians London (London: s.n., 1660).

${ }^{32}$ The Diary of Samuel Pepys, 22 January 1666, online: <http://www.pepysdiary.com/archive/1666/ 01/>, accessed 17 August 2011.
} 


\section{Aaron Mauck}

younger leadership, more familiar with the new philosophy and more accepting of its goals. In fact, both Francis Glisson, who replaced Edward Alston as President, and George Ent, who replaced Baldwin Hamey $\mathrm{Jr}$ as consiliarus had, like Merrett, been part of the 1645 Group and founding members of the Royal Society. ${ }^{33}$ The fact that Merrett was not granted a similar leadership role, and was in fact stripped of his status as Harveian Librarian, indicates the extent of his alienation from the Royal College in the aftermath of the fire.

Nevertheless, the change in leadership offered new opportunities for Merrett to return to professional relevance, even as it signalled the beginning of a significant schism within the Royal College. As a manifest expression of long-latent tensions, it marked the beginning of open conflict between those holding different visions for the future of medicine. While the ensuing pamphlet war was ostensibly concerned with the incursion of apothecaries into areas of practice traditionally held by elite physicians (especially diagnosis), it thus hinged on the question of what sort of knowledge was best suited for medical practice: either the preservation of health through learned advice rooted in Galenic principles; or the restoration of health through the application of specific therapies derived from experiment. ${ }^{34}$

This pamphlet war is generally taken to have begun with an attack on Galenism by Joseph Glanvill, an Anglican clergyman and member of the Royal Society, in his book Plus Ultra. ${ }^{35}$ Conceived as a supplement to Thomas Sprat's History of the Royal Society, Plus Ultra directly contrasted the new philosophy with the classical sources of knowledge privileged by elite physicians. According to Glanvill, excessive reliance on the ancients had crippled progress in medicine through resort to speculative reasoning: 'the Philosophers of elder times, though their Wits were excellent, yet the way they took was not like to bring much advantage to knowledge, or any of Uses of humane life. ${ }^{36}$ Though Glanvill (speaking, he suggested, for the Royal Society as a whole) acknowledged the value of 'all the useful Theories and helps we have from them', his appreciation did not extend the practical application of theory to medicine: 'the unfruitfulness of those Methods of Science, which in so many Centuries never brought the World so much practical beneficial knowledge as would help the Cure of a Cut Finger, is a palpable argument, that there were fundamental mistakes, and that the Way was not Right'. ${ }^{37}$

Sprat's work had similarly questioned the usefulness of classical knowledge, underscoring the superiority of the new philosophy over Aristotelianism, and arguing that the experimental programme would provide the foundation for both true religion and domestic peace and prosperity. ${ }^{38}$ For both authors, the limitations of classical knowledge could only be overcome by the wholesale adoption of the new philosophy as the primary method of knowledge production.

\footnotetext{
${ }^{33}$ Cook, Decline, op. cit. (note 20), 162.

${ }^{34}$ Harold J. Cook, 'Physicians and the New Philosophy: Henry Stubbe and the VirtuosiPhysicians', in French and Wear (eds), op. cit. (note 1), 246-71.
}

\footnotetext{
${ }^{35}$ Joseph Glanvill, Plus Ultra: Or, the Progress and Advancement of Knowledge Since the Days of Aristotle (London: Printed for James Collins, 1668).

${ }^{36}$ Ibid., 7.

${ }^{37}$ Ibid., 6-7.

${ }^{38}$ Thomas Sprat, A History of the Royal Society (New York: Kessinger Publishing, 2003).
} 
In 1670 , the political pamphleteer and physician Henry Stubbe, possibly writing at the behest of the ousted Baldwin Hamey Jr, published two pieces in response to this interpretation of the ancients. Both The Plus Ultra Reduced to a Non Plus, ${ }^{39}$ his reply to Glanvill, and Legends, No Histories, ${ }^{40}$ his reply to Sprat, represented the Royal Society as a threat, not only to the foundations of natural knowledge, but to the stability of the prevailing religious and political order. ${ }^{41}$ Whereas Sprat argued that the modesty, humility, and cautious scepticism elicited by the scientific temperament would reduce sectarian religious enthusiasm and discourage submission to papal authority, Stubbe saw the new philosophy as a gateway to the acceptance of a variety of heretical positions, from atheism to papacy. ${ }^{42}$

Glanvill and Sprat's attacks on elite medicine were also worrying, as Stubbe could not see any great improvements deriving from the new methods. 'Most that the Novellists have done,' Stubbe argued, 'is to find out new reasons for an antient practice'. ${ }^{43}$ While he acknowledged certain limitations of Galenism, the experimental programme undermined the professional authority of medicine by privileging speculative treatments that promised cures but often failed to deliver them.

Many physicians critical of Galenic practice had indeed emphasised the material 'cure' of disease. Thomas Sydenham would eventually suggest that a physician was to cure disease and 'do naught else'. ${ }^{4}$ But Merrett did not consider prevention and treatment to be fundamentally incompatible - even if different means were employed to achieve the two ends. While Glanvill had called into question the basic efficacy of Galenic approaches to health and illness, Merrett believed that certain aspects of experimentation could be incorporated into the established Galenic repertoire without undermining its central tenets. ${ }^{45}$ In claiming this middle ground, Merrett was joined by Jonathan Goddard, another veteran of the 1645 Group and founding member of the

\footnotetext{
${ }^{39}$ Henry Stubbe, The Plus Ultra Reduced to a Non Plus: Or, A Specimen of some Animadversions upon the Plus Ultra of Mr Glanvil (London: s.n., 1670).

${ }^{40}$ Henry Stubbe, Legends no Histories: Or, A Specimen Of some Animadversions Upon the History of the Royal Society (London: s.n., 1670).

${ }^{41}$ For an account of Stubbe's involvement in this pamphlet war, see James Jacob, Henry Stubbe, Radical Protestantism and the early Enlightenment (Cambridge: Cambridge University Press, 2002), Ch.5, 'Aristotle on the Ale Benches'.

${ }^{42}$ Stubbe's motivations in publishing against the Royal Society are complex and remain a matter of some speculation. Early interpretations of Stubbe's position have tended to see him either as a reactionary holdover of more traditional medical practice, or as an opportunist concerned solely with the commercial consequences the Royal Society might have upon medicine. See for instance Richard Foster Jones, Ancients and Moderns: A Study of the Rise of the Scientific Movement in Seventeenth-Century England (New York: Dover Publications, 1982), 244-63; G.N. Clark, A History of the Royal College of Physicians of London (London: Clarendon Press for
}

the Royal College of Physicians, 1964), 311-12. Recent scholarship on Stubbe has shown both interpretations to be problematic. Prior to the pamphlet war Stubbe was considered something of a political and intellectual radical; in the words of James Jacob, a 'Hobbesist Independent, quasiHarringtonian Army Republican' in idem, op. cit. (note 41). Harold J. Cook has suggested that by the 1660 s, however, Stubbe's positions would not have been considered significantly out of the mainstream: Cook, op. cit. (note 34).

${ }^{43}$ Henry Stubbe, op cit. (note 40), Preface, n.p.

${ }^{44}$ For more on Sydenham's Reform agenda, see Andrew Cunningham, 'Thomas Sydenham and the "Grand Old Cause",, in French and Wear, op. cit. (note 1), 164-90.

${ }^{45}$ Daniel Coxe, A Discourse wherein The Interest of the Patient in Reference to Physick and Physicians is Soberly Debated (London: Printed by C.R., 1669); Christopher Merrett, A Short View of the Frauds and Abuses Committed by Apothecaries (London: Printed for James Allestry, 1670); Jonathan Goddard, A Discourse Concerning Physick, and the Abuses thereof by Apothecaries (London: Printed by John Martyn and James Allestry, 1670). 


\section{Aaron Mauck}

Royal Society, and Daniel Coxe, a much younger Fellow who had only been elected to the Royal College in $1665 .{ }^{46}$ As Coxe succinctly expressed their position, 'medicines which have a sensible operation, specifics, and chymical remedies, have all a subserviency to [Galenic] method. ${ }^{47}$

They further argued that the introduction of drug production into elite practice could alleviate competitive tensions between physicians and apothecaries. ${ }^{48}$ This would ensure learned and authoritative oversight of the production process, while expanding the revenue base for physicians at the expense of their professional rivals. As it would entail further exploration into the properties of the constituent ingredients of complex remedies, it was hoped that it might also lead to new discoveries.

Admittedly, the authors seldom provided concrete examples of the ways in which treatments were likely to improve through drug production, or of the specific experimental methods to be employed. The few examples of experimentation they offered suggested that new cures might emerge as much from the learned evaluation of existing treatments as from the discovery of new substances; for instance, Merrett emphasised the way in which distillation and precipitation might allow physicians to better evaluate the fundamental properties of existing therapeutic substances by examining their simple constituents. Through the exploration of simples, the experimenting physician could 'observe what medicines by precipitation or other ways, alter, destroy, or weaken one another, whereby of good ingredients singly used, a bad composition may be made, and therefore fail in the success expected. ${ }^{49}$

This was of course one of the central rationales for distillation offered by Paracelsus and Van Helmont, although like the chemical physicians who followed them, they generally sought to replace rather than augment the traditional practice. For Merrett, the experimental approach was instead most fruitful when it coupled practical art with learned judgment - a coupling that could only be accomplished by those who had received traditional philosophical training. Once developed, this approach could lead to new discoveries, no matter what artisanal activities were being explored. Virtually any trade could lead to improvements in natural knowledge about the body, provided their products and processes could be subjected to the discerning gaze of the learned physician.

While Merrett, Goddard, and Coxe were careful to highlight their ties to traditional Galenism, critics of their approach quickly came to associate it with Glanvill's sweeping attack on ancient knowledge. Following the publication of Merrett's A Short View of the Frauds and Abuses Committed by Apothecaries, an anonymous reply appeared entitled Lex Talionis, which accused Merrett of an underhanded attempt to promote the interests of the Royal Society by creating a wedge between physicians and apothecaries. ${ }^{50}$

\footnotetext{
${ }^{46}$ There appears to have been some confusion at the time as to whether the 'Coxe' involved in the pamphlet war was Daniel Coxe, or the older and more established Fellow Thomas Coxe. See Frank Ellis, 'The Author of Wing C6727: Daniel Coxe, FRS, or Thomas Coxe, FRS', Notes and Records of the Royal Society of London, 18, 1 (1963), 36-8.

${ }^{47}$ Coxe, op. cit. (note 45), 85.

${ }^{48}$ Merrett listed forty distinct complaints against the apothecaries referring to problems with the
}

production and composition of their drugs and other medicaments, their methods of selling them, and the techniques they employed to undermine the authority of the Royal College of Physicians, Merrett, op. cit. (note 45), 8-24.

${ }^{49}$ Ibid., 51-2.

${ }^{50}$ Anon., LexTalionis; Sive Vindiciae Pharmacoporum: Or A Short Reply to Dr Merrett's Book; and Others... (London: Moses Pitt, 1670). 
Merrett may have damaged his case for improved relations between the Royal College and the Royal Society in responding to this claim, as he insinuated that Henry Stubbe had authored the anonymous pamphlet, and then claimed - somewhat disingenuously - that the Royal Society actually posed little threat to the Royal College. ${ }^{51}$ He took the fact that many physicians remained active in both institutions as an illustration of continued mutual goodwill, ${ }^{52}$ and further suggested that loyalty of these members lay squarely with the Royal College. If the Royal Society came to be perceived as a threat to their livelihood, physicians would quickly leave. ${ }^{53}$

Despite this claim, Stubbe saw in Merrett's proposals the beginnings of a take over attempt by the Royal Society. In Campanella Revived, ${ }^{54}$ a further attack on the new philosophy, he denied authorship of Lex Talionis (probably truthfully), ${ }^{55}$ but ultimately agreed with its main point concerning Merrett's loyalties by describing Merrett's pamphlet as yet another of the 'puny strategems of the virtuosi' for grabbing power. ${ }^{56}$ He further argued that the proposal for closer relations between the activities of physicians and virtuosi would fail to improve medicine, as virtuosi lacked the medical expertise necessary to bring about such improvements. In other words, they lacked the traditional training necessary for the exercise of learned judgment. ${ }^{57}$

This exchange between Merrett and Stubbe produced little resolution, resulting in détente rather than outright victory. Most of those involved simply appear to have eventually lost interest in the issue as the years dragged on. Glanvill remained an active participant until 1673, when he grew tired of refuting Stubbe's criticisms of the Royal Society and the accusations of impiety levelled against him. Stubbe turned his pen away from medicine and towards the Third Dutch War. ${ }^{58}$ Merrett continued to promote his reform programme, ${ }^{59}$ but appears to have become increasingly concerned with seeking a legal recourse for what he perceived as his ill-use at the hands of the College.

Despite their exhaustion with the issue, both Stubbe and Merrett - probably the two most active participants in this exchange of pamphlets - remained devoted to restoring some sense of coherency to medicine. For Stubbe, this could be best accomplished by more vigilant observation of existing regulatory mechanisms controlling the activities of apothecaries and other potential commercial threats. For Merrett, it required fundamental transformation of the way medicine was understood and practised. Order

\footnotetext{
${ }^{51}$ Christopher Merrett, A Short Reply to the Postscript, \&c of H.S. Shewing his Many Falsities in Matters of Fact... (London: printed by T.R. for James Allestry, 1670).

${ }^{52}$ Ibid., 3.

${ }^{53}$ Ibid.

${ }^{54}$ Henry Stubbe, Campanella Revived: Or, An Enquiry into the History of the Royal Society, Whether the Virtuosi There do not Pursue the Projects of Campanella for the Reducing England unto Popery (London: Printed for the Author, 1670).

${ }^{55}$ The style of Lex Talionis is different from that of Stubbe's responses to Glanvill and Sprat, and its criticisms far more pointed.It instead seems likely that Lex Talionis was written by a group of apothecaries in response to the attack Merrett levelled on their profession.
}

\footnotetext{
${ }^{56}$ Stubbe, op. cit. (note 54), postscript, 19.

57 'Let them therefore hence forward permit the Physicians to be Judges of their own Science, and give them the credit best to understand their own deficiencies, and the occasions of any failours in their practice. The blind may as well judge of colours, the insensible concerning the objects of feeling, as the Virtuosi of Physick.' Ibid., 22.

${ }^{58}$ For further discussion of Stubbe's later career and political activities, see Jacob, op. cit. (note 41).

${ }^{59}$ Coxe published one pamphlet relating to the question of reform, and Goddard two (one of which is now lost), as compared to Merrett's five between 1668 and 1673.For a complete list of the authors and pamphlets involved in this exchange, see Cook, op. cit. (note 34).
} 
could not be restored to commercial relations unless the profession itself was transformed.

\section{The Challenge of Competition: How to Control the Rogue Practitioners?}

Merrett used the pamphlet war as an occasion both to present himself as a moderate voice among an increasingly immoderate chorus, and to present explicit reforms that could help restore congenial relations between the two communities with which he was most directly involved. Both were undoubtedly efforts at self-promotion, as bringing about better relations between physicians and virtuosi could only help him improve frayed relationships with his colleagues. However, they also reflected his long experience with the challenges of regulation, both as a private practice physician and as a Censor.

Like most physicians practising in this period, Merrett perceived the problem of competition as arising from growing cracks in the edifice of the established professional order. By charter, medical services were divided into a tripartite structure in which physicians diagnosed disease and offered prognosis through observation and discourse with patients; apothecaries made and sold drugs according to physicians' orders; and surgeons 'laid on hands' by setting bones, amputating limbs, bloodletting, etc. This order was supported by English common law, but was difficult to enforce. ${ }^{60}$ Although the Royal College sought to punish individuals who strayed too severely from the established relations, ${ }^{61}$ their activities often resulted in piecemeal and inconsistent punishments for the various apothecaries, travelling empirics, drug peddlers, midwives, and traditional healers practising on the London scene. During the time in which Merrett was an active Fellow, virtually no prosecutions were undertaken. ${ }^{62}$

Traditional physicians also had to contend with changing consumer dynamics in the city, which encouraged practitioners to move away from their clientelistic emphasis on personal counsel towards the production and sale of medical commodities. ${ }^{63}$ The replacement of personal ties with money ties offered significant advantages for the practitioner, allowing greater freedom of movement and the capacity to scale the supply of products to the demand. ${ }^{64}$ The traditional division of medical labour therefore came under increasing pressure as the century progressed, both from without (via a

\footnotetext{
${ }^{60}$ English common law allowed anyone to practice medicine provided they had patient consent, although if the patient died as a result they could be tried for a felony. Merrett, op. cit. (note 31), 66.

${ }^{61}$ The Charter of the Royal College gave members the right to judge medical practitioners in London and within seven miles of the city, and to admit to the profession those it deemed sufficiently qualified.This effectively made the Royal College an institutional arbiter of medical innovations. See Cook, Decline, op. cit. (note 20), 20-1.

${ }^{62}$ Cook, ibid., Appendix 2.For further discussion of the wide range of medical practitioners working in England at this time, see Margaret Pelling, The Common Lot: Sickness, Medical Occupations, and the Urban Poor in Early Modern England (New York: Longman, 1998).
}

\footnotetext{
${ }^{63}$ The increase in consumer demand for medicine and medical advice in the seventeenth century has recently been demonstrated in Ian Mortimer, The Dying and the Doctors: The Medical Revolution in Seventeenth Century England (Woodbridge: Royal Historical Society, 2009).

${ }^{64} \mathrm{On}$ the expansion of the market in England in the seventeenth century, see Joan Thirsk, Economic Policy and Projects: The Development of a Consumer Society in Early Modern England (Oxford: Oxford University Press, 1978); Margaret Spufford, The Great Reclothing of Rural England: Petty Chapmen and their Wares in the Seventeenth Century (London: The Hambledon Press, 1984); Linda Levy Peck, Consuming Splendor: Society and Culture in Seventeenth Century England (Cambridge: Cambridge University Press, 2005).
} 
skyrocketing number of individuals practising outside of the official professional structure) and within (via practitioners seeking to branch out from their prescribed roles). ${ }^{65}$

For Merrett, as for many other physicians, one of the greatest threats to the established professional order appeared to be apothecaries who counselled and diagnosed patients in addition to selling drugs. ${ }^{66}$ While this threat diminished after 1703 with the finding of the Rose Case (in which it was decided that apothecaries had the legal right to diagnose but could not charge for the privilege), ${ }^{67}$ competition with apothecaries remained intense throughout the second half of the seventeenth century.

Recognising the similarities in the work of apothecaries and virtuosi-physicians, Merrett sought to distinguish between them based on their relative capacity for learned judgment, and to stress the need for more direct oversight over the production techniques apothecaries employed. Such regulatory measures were well within the legal rights of the Royal College, and had constituted the primary means of restricting the practices of apothecaries in the past. A return to the status quo ante of professional relations was thus called for in the short term.

But oversight could be nothing more than a stop-gap solution to problems endemic in the growing medical marketplace. Inspections and prosecutions could not yield lasting results, either because they were unsystematic and costly, or because the unstable political fortunes of the Royal College limited its ability to follow through on its regulatory rights. ${ }^{68}$ A permanent solution lay not in simply confining the activities of apothecaries, as Stubbe had argued, but in assuming these activities oneself. In newly commercial London, it was not enough to simply restrict trade; physicians also had to provide a superior product.

Thus, Merrett concluded that 'as affairs now stand between the Physicians and Apothecaries of England... [the physicians] ought to make their own medicines if they intend to support their own faculty and the honour of it'. This would ultimately improve the quality of the product delivered to the consumer by 'the avoiding of the insufferable charges imposed upon our patients by the high bills of the Apothecaries, and the uncertainties of our success by reason of their detracting, substituting, putting in false, decayed and unwholesome ingredients into our receipts. ${ }^{, 6}$

Merrett provided a legal rationale for this expansion of practice by repeating the popular claim that physicians had historical priority in drug production. ${ }^{70} \mathrm{He}$ suggested that Greek physicians regularly experimented with drugs prior to the appearance of apothecaries by serving as pharmacopaei, or makers of medicine. Apothecaries were initially pharmacopolae, or simple sellers of prepared medicines, until physicians gave over drug production to these assistants and commercial distributors. ${ }^{71}$

\footnotetext{
${ }^{65}$ The estimated ratio of medical practitioners to the total London population in the seventeenth century is 1:400. Margaret Pelling and Charles Webster, 'Medical Practitioners', in Charles Webster (ed.), Health, Medicine and Mortalityin the Sixteenth Century (Cambridge: Cambridge University Press, 1979).

${ }^{66}$ Armytage, op cit. (note 20).

${ }^{67}$ For further discussion of this case and its consequences, see Harold J. Cook, 'The Rose Case Reconsidered: Physic and the Law in Augustan
}

\footnotetext{
England', Journal of the History of Medicine, 45 (1990), 527-55.

${ }^{68}$ Harold Cook, Decline, op. cit. (note 20), Ch.4.

${ }^{69}$ Merrett, op. cit. (note 51), 15.

${ }^{70}$ Similar claims were made by other participants in the pamphlet war, notably by Jonathan Goddard who argued that both Galen and Hippocrates had produced drugs.Goddard, op. cit. (note 45), 5-9.

${ }^{71}$ Merrett, op. cit. (note 51), 15. Merrett further supported this by pointing out that the etymology of the word 'apothecary' suggests the word 'box,'
} 


\section{Aaron Mauck}

Merrett further argued that drug production was needed to improve patient safety and address the poor quality of the care delivered by apothecaries. His pamphlets were studded with anecdotes describing the fatal errors apothecaries had made through poor diagnosis and dangerous production practices. Apothecaries were presented as more dangerous to the public than 'all the others... Divines, Quacks and Mountebanks, \&c'. ${ }^{72}$ They were a 'poysonous weed', whose late budding and growth threatened to 'choak the sweet flower' of the elite physician's practice. ${ }^{73}$ Merrett referred, for instance, to an unnamed apothecary working in the Strand, "who with three doses of Mercurius Dulcis, given against the Worms of three Children, did the same day worm 'em out of their lives', and to another, whose prescribed treatment for ear inflammation '[forced] the inflammation into the brain, immediately occasioned a phrensie, and not long after a Corps' ${ }^{74}$

While claims were hardly likely to improve professional relations, Merrett took pains to distinguish between so-called 'honest' apothecaries, who remained wedded to traditional practices and accepted complete subservience to physicians, and 'practising' apothecaries, who put patients at risk by claiming an expertise in medical practice, and assuch, capacity for learned judgment that they themselves lacked. In a move designed to promote honest practices among apothecaries, Merrett proposed that all members of that profession thus take an oath every seven years in which they would 'praepare and dispense the praescriptions of Physicians exactly without the least alteration, omission, or addition'. Apothecaries were also encouraged to support physicians in their attempts to regulate the profession by opposing the 'frauds and insinuations of Empiricks and Practising Apothecaries'. ${ }^{75}$

Merrett suggested that physicians take a similar oath at regular intervals that put them in mind of their own duties to the honest apothecary, and constrained their future drug production practices to 'such drugs that are very difficult, requiring art and care, and whereon the weight and principal efficacy of Curing great Diseases doth depend'. ${ }^{76}$

These oaths implied an inter-professional arrangement based on the gentlemanly principles of mutual trust and goodwill. ${ }^{77}$ If apothecaries continued to undermine the commercial viability of elite physicians by diagnosing disease and prescribing remedies, professional relations would remain antagonistic and physicians would be forced to radically expand their production practices in order to compete. If apothecaries returned to their traditional role, much of the old division of labour between the two professional bodies would be restored. Apothecaries would continue to mix and supply most drugs to

denoting the 'multitude of boxes placed in their shops, and containing all sorts of drugs.' Christopher Merrett, The Accomplisht Physician, the Honest Apothecary, and the Skilful Chyrurgeon (London: s.n., 1670), 40.

${ }^{72}$ Ibid., 39.

${ }^{73}$ Ibid., 40.

${ }^{74}$ Ibid., 45-8. These are two of seven examples of apothecaries' errors listed in this passage.

${ }^{75}$ Ibid., 85-6.

${ }^{76}$ This appears to be something of a retreat from Merrett's pamphlet of 1669 (Short View of the Frauds and Abuses Committed by Apothecaries), in which he gave no indication that physicians should restrain their practise of pharmacy to complicated drugs. Merrett offered no explanation for this change in tenor, although it may have been a result of growing recognition on his part that his pamphleteering was producing the opposite of its intended response.

${ }^{77}$ On the importance of trust in the production of scientific knowledge in the seventeenth century, see Steven Shapin, A Social History of Truth: Civility and Science in Seventeenth-Century England (Chicago, IL: University of Chicago Press, 1995). 
patients, although physicians would take over the production of certain complicated remedies in order to ensure their safety. ${ }^{78}$

It is impossible to determine the extent to which Merrett's appeals to apothecaries represented a genuine attempt at rapprochement - especially since Merrett was not simply advocating a return to the status quo ante of the sort promoted by Stubbe. Indeed it is easy to read his pamphlets as rhetorical machinations designed to give physicians an upperhand in the struggles against this emerging commercial threat (the nastiness of some of his criticisms against the apothecaries certainly suggests such a reading). ${ }^{79}$ But the fact that he proposed a compromise that placed complex drug production firmly in the hands of experimentallyinclined physicians indicates the extent to which he envisaged new intellectual and practical activities for improving the bargaining position of this profession.

\section{The Challenge of Education: What to Teach the Physician?}

While competition from apothecaries had to be addressed if physicians were to maintain legitimate authority over diagnosis and prescription, escaping the state of intellectual stagnation in which medicine appeared to languish required sweeping changes in the way physicians were educated. This was a decidedly upstream and non-regulatory solution to the problem of competition. Since Merrett viewed the threat from apothecaries and irregular physicians as largely deriving from limitations in existing medical knowledge and practice, he advocated measures to improve this knowledge through a geographical and topical expansion of subject matter, an embrace of new scientific discoveries coming from the Continent, and new artisanal knowledge coming from all directions at once.

This approach was consistent with the Baconian tradition in which Merrett was steeped, which held that philosophical and artisanal fields of knowledge production were equally capable of contributing to an understanding and mastery of nature. This had long been a central tenet of advocates of the new philosophy, serving as a basic principle of Boyle's Invisible College, Hartlib's Comenian Group, and Haak's 1645 Group.Although final judgment about scientific truth was always reserved for learned gentlemen, who possessed both the freedom and discernment to evaluate facts, the production of raw data about nature remained thoroughly democratic.

As head of the programme on the history of trades, Merrett sought to draw to the Royal Society knowledge related to a variety of artisanal practices, from traditional transformative arts such as refining, brewing, and smelting, to activities as far-flung as clock-making or moulding. It was hoped that through this the Royal Society would

\footnotetext{
${ }^{78}$ The rest of the oath encouraged 'gentlemanly' relations as well: '[physicians] shall depose all envy and malice, by desisting to decry or depress one another by clandestine sinister reflexions, but on the contrary, rather aiming at that part of the Gentleman, to give a generous Character to one another', Merrett, The Accomplisht..., op. cit. (note 71), 89.

${ }^{79}$ There is an apparent contradiction between Merrett's promotion of gentlemanly virtue and the
}

style of his critiques on apothecarial practice. This may be explained by the ambiguous position of physicians $v i s$ - $a$-vis those of higher social rank. Although physicians aspired to gentlemanly status, they were still forced to compete for scarce financial resources in ways that required decidedly ungentlemanly exchanges. See Cook, Decline, op. cit. (note 20), Ch.1. 


\section{Aaron Mauck}

become the nexus for all knowledge of trades that could be rendered into text, hopefully giving rise to fertile interactions between different fields.

Merrett had personally assisted this programme through his research. In preparing to translate The Art of Glass, for instance, he had sought out Italian glassmakers living in England in order to better understand the materials and practices Antonio Neri had included in his recipes for glass production. Merrett's vinicultural research contained similar recipes for identifying and curing the 'diseases of wine', ${ }^{80}$ and drew analogies between the treatment of these diseases and the treatment of his patients, implying that the tools applicable in one arena might also be applicable in the other. ${ }^{81}$

Although Merrett promoted the acquisition of artisanal knowledge as an important part of reformed medical education, he acknowledged the continued primacy of established university training. Merrett's 'reformed' student, like his traditional counterpart, was expected to possess a working knowledge of Latin and Greek and to have studied philosophy at either Cambridge or Oxford. Through such study the student 'learns to speak like a Scholar, and is informed in the principles of Nature, and the constitution of natural bodies'. ${ }^{22}$ This training was not only required for the physician to exercise authority over other medical practitioners, but also provided the foundations of learned judgment that distinguished his understanding of nature from the tacit and contingent natural knowledge produced by artisans.

While the medical statutes of the mid-seventeenth century specified that the student spend seven years at either Oxford or Cambridge, however, Merrett proposed that the student spend only two years there, and devote much of this time to the direct study of nature rather than to disputation or philosophical training. ${ }^{83}$ The student was then expected to leave the university in pursuit of practical knowledge of the body and treatment techniques.

This knowledge began with anatomy - a subject that was much out of favour with chemical physicians, but to Merrett the 'basis and foundation, whereon the weighty structure of physick is to be raised' ${ }^{84}$ Merrett suggested that the student thus leave England and enrol in the Collegium Anatomicum in Leiden, ${ }^{85}$ where he was to supplement the abstract anatomical training he received with its practical application in the hospital. Through such training the student would develop a better understanding of

\footnotetext{
${ }^{80}$ Michael Best, op. cit. (note 16).

${ }^{81}$ Merrett's interest in fermentation and brewing, particularly in relation to sparkling wines, has recently become a subject of some interest due to its apparent priority over the French development of techniques for producing sparkling wines.

${ }^{82}$ Merrett, The Accomplisht,.., op . cit. (note 71$), 17$.

${ }^{83}$ For discussion of the requirements for the university degree in medicine during this period see Phyllis Allen, 'Medical Education in Seventeenth Century England', Journal of the History of Medicine and the Allied Sciences 1, 1 (1946), 115-43;

R.G. Frank, 'Science, Medicine, and the Universities of Early Modern England: Background and Sources', History of Science, 11 (1973), 194-216; A.H.T. Robb-Smith, 'Medical Education at Oxford and
}

Cambridge Prior to 1850', in F.N.L. Poynter (ed.),

The Evolution of Medical Education in Britain

(Baltimore, MD: Williams and Wilkins, 1966), 19-52.

${ }^{84}$ Merrett, The Accomplisht..., op. cit. (note 71), 19.

${ }^{85}$ Leiden was a particularly popular destination for English medical students due to the short time required to obtain a degree (weeks or months rather than years). However, Leiden also placed greater emphasis on clinical training than philosophical disputation and was thus consistent with Merrett's expectations for medical education. See G.A.

Lindeboom, 'Medical Education in the Netherlands, 1575-1750', in C.D. O'Malley (ed.), The History of Medical Education (Berkeley, CA: University of California Press, 1970). 
the physiological foundations of diagnosis and prognosis - the two most important tools of elite medical practice. ${ }^{86}$ Similar training was then to be taken at the famous L'HôtelDieu and La Charité hospitals in Paris. ${ }^{87}$

Hospital education would also provide the student with a greater understanding of experimental pathology, especially if the student was willing to branch out from the passive observation of illness to active manipulation of bodies through empirical exploration. Merrett thus suggested that students evaluate the action of various substances within the body by poisoning animals and dissecting them to uncover their specific pathological effects. ${ }^{88}$

In addition to private experiments of this sort, Merrett proposed that the student apprentice himself to an apothecary for the period of a year, and thereby learn the art of composing drugs. This would not only enable physicians to ensure their safety and efficacy, but would also add legitimacy to the physician's efforts at regulation. Otherwise 'it would be adjudged ridiculous, should a Physician undertake to reprehend, and afterward bend his force, to suppress and decry Apothecaries, privately or publickly, without having first acquired a particular experience in their Art. ${ }^{89}$ It was precisely the lack of this knowledge that had undermined previous attempts by physicians to regulate their counterparts. ${ }^{90}$ It was equally important for physicians to become acquainted with surgery, as in England they also claimed superintendence over this group. Merrett therefore proposed that the student spend an additional year in apprenticeship to a surgeon, observing technique and discovering the rules by which this craft was practised. ${ }^{91}$ Merrett did not go so far as to suggest that the student actually perform surgery, but rather that he develop his understanding through 'ocular inspection' and the handling of instruments. ${ }^{92}$

The final stage in Merrett's proposed education was even less traditional, being the equivalent of a natural historical 'grand tour' of the Continent. Merrett did not consider medical education complete until the student had moved beyond the pure pursuit of

\footnotetext{
${ }^{86}$ Holland was known for imposing a less sharp division between physicians and other medical practitioners than either England or France, thus allowing the physician greater opportunities for engaging in activities otherwise left to surgeons or apothecaries. This may help explain the prominence of Holland in Merrett's plans. See Harold J. Cook, The Trials of an Ordinary Doctor: Joannes Groenevelt in Seventeenth Century London (Baltimore, MD: Johns Hopkins University Press, 1994).

${ }^{87}$ A period of training through apprenticeship was an expected part of the training of a young physician in England.Hospitals served as appealing sites for such training due to the large number of patients seen.

${ }^{88}$ Christopher Merrett, The Character of the Compleat Physician, or Naturalist (London: Printed for E.H., 1680), 2.

${ }^{89}$ Merrett, The Accomplisht..., op. cit. (note 71), 20.

90 'Here it is again, the vulgar Physician is wrapt up in a cloud, and the Apothecaries dance round him;
}

he praescribes Medicines he never saw, they praepare them according to their own will and pleasure,' Ibid. The vagaries of the production process could also be effectively addressed by replacing the complex remedies favoured by apothecaries with remedies by simples. Merrett, op. cit. (note 88), 4.

${ }^{91}$ Although some surgeons were considered quite learned, Merrett also considered this profession under-regulated, and discussed the poor state of surgery in The Accomplisht Physician. In pointing to the failings of surgery, Merrett diverged slightly from the focus he and his fellow reformers usually placed on the depravations of the apothecaries, see Cook, op. cit. (note 34), 261.

${ }^{92}$ Merrett, The Accomplisht..., op. cit. (note 71), 21. Merrett was thus careful to avoid suggesting an expansion of the physician's practice to actual 'laying on hands.' While the physician was encouraged to make drugs, surgery was to remain in the hands of surgeons. 


\section{Aaron Mauck}

medical knowledge to embrace the full range of activities and forms of knowledge pursued by mankind. This allowed the aspiring physician to contribute to a variety of human pursuits, rather than focusing solely on the advancement of his profession:

As a Picture is raised to the highest point of admiration by the variety of excellent colours; so the Intellectuals of a Physician are incomparably adorned with the addition of those various accomplishments, his Travails through several Countreys afford. Wherefore ought not to content himself, with the sole improvement of his profession, for so vast an expense, trouble, and passing through so many dangers, but like an expert Chymist, draw essences of all discourses, the ingenuity of those Travailers from other parts of the world do offer. ${ }^{93}$

The range of materials the physician was expected to survey was prodigious. In Rome, it was holy relics and antiquities; in Naples, the wonders of nature found about the Pazzuolo. In Liverno, the student should observe shipbuilding, fountains, and art. In Pisa, a church steeple, in Lucca, ramparts, and in Milan, the Citadel. The student should then pass from Italy to Basel where he was to view Holbein's Dance of the Dead, and from there to Strasbourg, where he was to examine the intricacies of the clockwork in the Cathedral of Our Lady of Strasbourg and marvel at the height and artifice of the steeple. Eventually, the student was to make his way to Heidelberg and examine the structure of the Prince Elector Palatin's castle as well as his cavalry. From there he should pass to Mainz to examine a perpetuum mobile that had kept exact time for seven years without being wound. In virtually all of these cities Merrett implored the student to stop and sample the local vintage of wine and to survey different techniques of wine production. In total, Merrett listed twenty-seven different cities the student should visit on his way to becoming a fully educated physician. ${ }^{94}$

In a smaller piece written a decade after this proposed travel plan, Merrett argued that the physician should also become acquainted with 'philosophical trades' such as those of refiners and dyers. Members of such trades were familiar with the methods of chemistry, and through experimentation might 'without much difficulty discover, the compounds of Medicinal Waters, which hath hitherto puzzled all the World.' Merrett saw similar promise in all trades, to the extent that 'no Manufacture but affords some light in Physics'. 95 Activities appearing to have little bearing on medicine or its reform were thus fundamental to improved medical knowledge, as this knowledge was ultimately tied to a broader understanding of nature available to artisans manipulating her products.

Knowledge of philosophical trades was also required for physicians to properly assess the foundations of efficacy, as 'from ignorance of these things proceeds the doctrine of occult qualities'. Improper method made a muddle of everything, ultimately rendering it impossible for the physician to distinguish good remedies from bad ones or to discern the causes of their action within the body. 'Hence Receipts get credit, Medicines so often altered, and new ones gap't after, whereof as yet there is no end. ${ }^{96}$

As is clear from such statements, Merrett's proposed educational reforms rested on an epistemological foundation somewhat different from that supporting established elite

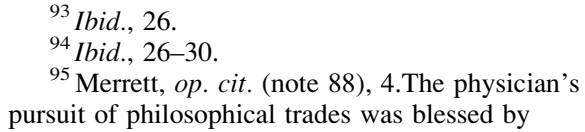

${ }^{93}$ Ibid., 26.

${ }^{94}$ Ibid., 26-30. pursuit of philosophical trades was blessed by

classical precedent, since the word 'physician' itself derived from the Greek physis, a term encompassing the entirety of nature. Idem, 2-3.

${ }^{96}$ Ibid., 5. 
medical education. While he continued to stress the primacy of Galenism, he also suggested a qualitative continuity between passive observation of nature or redirection of natural processes and active intervention in nature. Medicine was traditionally rational and purely observational. Unlike the tacit, embodied knowledge of the surgeon or the apothecary, physicians sought to treat patients solely on the basis of the external signs of illness exhibited by the body. This dissociation from manual work helped to demarcate medicine as superior to other forms of medical knowledge.

Merrett sought to undercut this existing intellectual and practical hierarchy in his educational proposals by pointing to the fruitfulness of experimental and artisanal forms of knowledge production. The transformative arts such as glassmaking, distillation, and refining, were as capable as pure observation of producing valid natural knowledge and of improving the state of medicine. In suggesting continuities between observation and intervention, Merrett thus encouraged the adoption of an active and even physical style of knowledge production, to supplement the dispassionate and discerning gaze on which physicians tended to rely. ${ }^{97}$

Merrett was hardly the first to advocate for such changes in the way medicine was taught. Throughout the Interregnum, university education had been the subject of fierce debates, reflecting the intimate connections thought to exist between the educational and the political order. Like Merrett, earlier advocates of educational reform, such as the radical cleric and physician John Webster and the chemical physician Noah Biggs, had challenged excessive reliance on ancient sources and dogmatic methods. However, they had sought to completely replace the traditional curriculum with an updated one of their own choosing. In the case of Webster, for instance, this mostly derived from Bacon and Robert Fludd, and consisted of an eclectic admixture of experimentalism, alchemy, and astrology. ${ }^{98}$ In contrast, Merrett clearly wished to retain core elements of traditional Galenic training, making it the foundation upon which his untraditional proposals rested.

Merrett's reforms obviously lacked concrete strategies for implementation. No student would ever be able to undertake the kind of education he had proposed, no matter how intrepid they might be. But unlike his predecessors, Merrett appears to have been less interested in implementation than in exhibiting the range of available knowledge from which the physician might draw his understanding of nature, the human body, and human artifice. They served his rhetorical purpose of encouraging a broadened conception of medical education that nonetheless remained grounded in established philosophical training.

\footnotetext{
${ }^{97}$ Merrett thus recognised many of the advantages of view promoted by early Royal Society supporters, such as Robert Boyle and Robert Hooke, according to which experience and tacit understanding were to be privileged over the received authority. Raw experience could be improved upon, however, through the application of systematic principles of method, such as those ideally espoused in Galenic medicine. On the importance of experience in creating scientific knowledge, seefor instance Steven Shapin and Simon Schaffer, 'Leviathan' and the Air-pump: Hobbes, Boyle, and the Experimental Life (Princeton, NJ: Princeton University Press, 1985);
}

Steven Shapin, 'The House of Experiment in Seventeenth-Century England', Isis, 79 (1988), 373-404; Peter Dear, Discipline and Experience: The Mathematical Way in the Scientific Revolution (Chicago, IL: University of Chicago Press, 1995); Robert Iliffe, 'Material Doubts: Hooke, Artisan Culture, and the Exchange of Information in 1670s London', British Journal for the History of Science, 28 (1995), 285-318.

${ }^{98}$ Allen Debus, Science and Education in the Seventeenth Century: The Webster-Ward Debate (New York: Elsevier, 1970). 


\section{Aaron Mauck}

\section{Conclusion}

Although the pamphlet war had provided Merrett with an opportunity to advocate for a wide range of reforms, it appears to have done little to restore the professional standing he once held. Indeed, he became increasingly unpopular in the years that followed as he mounted a vigorous legal campaign to be reinstated as Harveian Librarian. Insisting that this had been a lifetime appointment, Merrett appears to have refused to relinquish the items he had rescued from the College House until a satisfactory resolution could be reached. Rather than accede to this somewhat extortionate demand, in 1681, Merrett was effectively expelled from his Fellowship on the pretext that he had failed to attend meetings. The next President, John Micklethwaite, took the matter of the remaining books to the Chancery Court, in a complicated legal proceeding lasting two years. Finding in favour of the Royal College, the Court ordered Merrett to return all he had saved to the new College Quarters at Warwick Lane. ${ }^{99}$

The expense of these legal proceedings may have played a role in his eventual expulsion from the Royal Society two years later - for being in arrears in his subscription payments since $1668 .{ }^{100}$ Merrett spent the remaining years before his death in 1695 at his house at Hatton Garden, apparently engaged in private practice and peddling remedies of his own design, but staying well beyond the fray of professional politics. ${ }^{101}$

The personal and professional failures Merrett experienced in his later life followed an intertwined path. While Merrett was among several physician-virtuosi to ascend to positions of authority within the Royal College, he is the only one to have experienced such a precipitous decline. Jonathan Goddard, who like Merrett advocated a rapprochement between physicians and virtuosi rooted in the production of drugs, left the pamphlet war unscathed, and continued to play an active role in both the Royal College and the Royal Society until his death in 1675. It thus seems likely that Merrett was already the object of some antipathy by the time the pamphlet war began, which perhaps explains why his activities appeared to have received special critical scrutiny.

Nevertheless, the attacks that critics such as Stubbe levelled against his proposals were rooted in real concerns for the future of the profession. If medicine was no different in kind from knowledge of the rest of nature, then physicians could not legitimately claim a monopoly over the human body, no matter how much traditional training they had received. Under such circumstances the virtuosi inspired by natural history, and who made the entirety of nature his purview, could be seen as superior to the physician inspired by natural philosophy, who focused solely on the human body at the expense of the rest of the world. Medicine was therefore at some risk of becoming a minor satellite of the new philosophy - especially if its physicians chose to adopt the same methods used by the virtuosi in an attempt to improve their competitive advantage in the medical marketplace.

\footnotetext{
${ }^{99}$ TNA RCP-LEGAC/ENV 90

${ }^{100}$ The precarious finances of the Royal Society necessitated the expulsion of several non-paying members at this time. See Hunter, The Royal Society..., op. cit. (note 1), 35-49.
}

\footnotetext{
${ }^{101}$ In an undated broadsheet from later in his life, Merrett combined an advertisement for this remedy with a promise to address his critics by revising and reprinting some of his older books, although no reprints appear to have been published. Bodleian, MS: Rawl. C. 419.
} 
When Merrett's proposed reforms are interpreted in this way, it is easy to understand why some saw his embrace of experimentalism and artisanal knowledge as potential threats to traditional practice. As much as the activities of apothecaries constituted a commercial challenge in their own right, it seemed possible to address these through existing (though admittedly inefficient) regulatory measures. The qualitative distinction between medical knowledge and knowledge of the rest of nature would thus remain intact, and physicians could continue to claim a monopoly over their field.

However, Merrett does not appear to have seen in his reform proposals the same wholesale reformulation of medical theory and practice that his critics saw. Rather, in his idealised vision of medical regulation and education, experimentation and artisanal knowledge added to traditional practice without radically reformulating what came before. At the heart of medicine one continued to find the Galenic mainstays of learned observation and prevention. Knowledge of the body thus remained distinctive from other kinds of knowledge, if only because it was best obtained by those who had first received philosophical training.

The failure of Merrett's reform effort did not result in a wholesale usurpation of medicine at the hands of the Royal Society juggernaut, though it did result in permanent changes in the way in which traditional physicians presented themselves. Harold J. Cook has argued that traditional physicians quickly adopted a series of rhetorical shifts in which the old emphasis of Galen was replaced by a new emphasis of Hippocrates as the intellectual progenitor of medicine. It also became commonplace for physicians of all stripes to argue that their medical knowledge derived from empirical experience, whether or not it did, and to promote monocausal theories of disease aligned with this experience. Although the pursuit of universal cures gradually began to eclipse the emphasis on prevention and tailored medical advice, many aspects of Galenic practice in fact remained in use for centuries longer. ${ }^{102}$

Remarkably, this unplanned outcome seems largely consistent with the kind of reforms Merrett advocated. In practice, it was apparent that both medical approaches could comfortably coexist with little threat of contradiction, as they had different goals and were relevant to different aspects of the disease experience. While the conditions of knowledge production promoted by the new philosophy undoubtedly posed an intellectual challenge to traditional medicine, this challenge was more palpably felt in the meeting halls of the Royal College and Royal Society than in the consulting rooms of private practice. Here, at least, the two traditions could comfortably coexist.

\section{Acknowledgement}

An earlier version of this paper was presented at the Early Sciences Working Group in the History of Science Department at Harvard University. Special thanks goes to Katherine Park, Steven Shapin, Elizabeth Yale, Michael Laycock, and two anonymous reviewers for their valuable suggestions. The author also thanks the Robert Wood Johnson Foundation Health \& Society Scholars program for its financial support.

${ }^{102}$ Cook, op. cit. (note 17), 422-4. 